\title{
Research Paper Socio-economic analysis of power loom industry in Karnataka a study on Thumkur district
}

\author{
A. P. Bhavya, G. N. Kulkarni, K. J. Sannapapamam and B. C. Ashwini
}

Correspondence to :

\section{A. P. Bhavya}

Department of Agricultural

Economics, University of Agricultural Sciences,

G.K.V.K., Bengaluru (Karnataka) India Email : bhavya816@ gmail.com
Paper History :

Received : 27.09.2017;

Revised : 17.01.2018;

Accepted : 01.02.2018
ABSTRACT : The Indian textile industry is a personification of Indian culture. It has always occupied a place of honour in the industrial system of India. The introduction of decentralized sector power looms dates back to 1904 when the Jahagirdar of Ichalkaranji (the princely state) gave encouragement to weavers to install power looms and improve their standards of living. The study was conducted in Tumkur district of Karnataka. The total sample size was 60 from three different taluks of Tumkur district, the result of the study showed that weaving was the main occupation for majority of 70 per cent of power loom weavers, the remain weavers interestingly 21.66 per cent of were involved in business activities along with weaving has the main occupation and they were selected weaving as a profession because of hereditary, 35.00 per cent weavers selected prospectus of job opportunity. Nearly 22 per cent of power loom weavers were illiterates, 55 per cent of weavers belonged to Devanga caste which traditionally had known to peruse weaving profession. And 45.00 per cent of power loom weaver had APL cards with grass annual income of 3,79,472.17 Rupees. Resham Saree has more cost of production than other power loom products of the study area and net return of the Resham Saree is 123.44 Rupess it is higher than LT and cotton silk Sarees with more than one B: C ratio. The lack of demand and threat from mil sector/ garments were the major constraints as expressed by power loom weavers, by the support of government sector with the creation of good market facility will help for improve the socio-economic conditions of the power loom weavers.

KeY Words : Power loom, Weavers, Resham, LT, Cotton Silk

How To Cite This PAPer : Bhavya, A.P., Kulkarni, G.N., Sannapapamam, K.J. and Ashwini, B.C. (2018). Socio-economic analysis of power loom industry in Karnataka a study on Thumkur district. Internat. Res. J. Agric. Eco. \& Stat., 9 (1) : 101-107, DOI : 10.15740/HAS/IRJAES/9.1/101-107. 